\title{
Joint Model of Corporate Default Intensities and Macroeconomic Dynamics
}

\author{
Maris Buikis, Riga Technical University, Tatjana Zidulina, Riga Technical University
}

\begin{abstract}
The paper presents a unified framework where a simple structural model of the macroeconomy is combined with an affine model of corporate default intensities. The main innovation of the paper is that the authors use structural macroeconomic framework, rather than starting from a reduced form representation and incorporate the structural model of macroeconomy in multivariate dynamics risk-neutral default intensities. The approach shows estimation of default intensity parameters from macroeconomic prospective. The combined model allows getting more precise corporate default intensities parameters and recovery rates that could be used for the fair CDS premium calculation.
\end{abstract}

Keywords -default risk event, default intensity, affine processes, macroeconomic factors, credit default swap, premium

\section{INTRODUCTION}

The role of financial markets is the most complex element in the modelling of financial risk and forecasting financial stability. Financial markets are extremely sensitive to new information and fluctuate sharply. In financial markets there are price crashes, liquidity shortages and propagation from one market to the other that affect a large number of agents at the same time. Economic factors and shocks also influence payoffs and market prices.

Credit markets are a substantial part of financial markets. Thesingle name structured credit products as Credit Default Swaps (CDSs) provide tremendous amount of information about the investors' risk preferences and play a crucial role in credit markets.A broad range of investors use CDS to express credit views. Commercial banks use them for hedging purposes. Central banks consider CDS as credit market-based indicator.

Since market agents rely on CDS, the "correct" pricing of such instrument is essential for them. One of the most difficult tasks in defining the price of CDS is to model default intensities and expected losses. Second task is sorting out how macroeconomic factors drive movements in interest rates and how they affect the behaviour of default risk.

The task of the paper is to present a unified empirical framework where a structural macroeconomic model is combined with an affine model of corporate default intensities.

There are three broadly defined research groups in understanding and modelling default intensities. First group studies the dynamics of physical or real-world default intensities (see, for example [4], [5]), while the second one studies the risk-neutral default intensities (see, for example, [7], [8], [10], [12], [13],). Research in the third group, which is still limited, studies joint multivariate dynamics of physical and risk-neutral intensities (see, for example, [1], [3], [9] and [15]).

All these studies developed models based on the assumptions of absence of arbitrage opportunities, but typically (with very few exceptions, such as [4]) left unspecified the relationship between the default intensities and other macroeconomic variables. Macroeconomist, on the other hand, have focused on understanding the relationship between different macroeconomic variables. In doing so, they have typically relied on the "expectations hypothesis", in spite of its poor empirical record. Combining these two lines of research seems fruitful and there are gains on both sides.

This paper contributes to a small but growing number of studies on the empirical properties of CDS spreads by constructing a joint model of default intensities and macroeconomic dynamics. Given the relatively short life of CDS market, most research on spreads has been conducted using bond data and U.S. market data. The paper focuses on CDS market analysis and uses European data instead of U.S. There are several reasons to analyse the CDS market. First, tt default swaps now play a central role in credit markets. Second, CDS spreads are probably a fairly clean measure of default and recovery risk compared to spreads on most corporate bonds. Third, swap contracts and notes on CDS indices are traded in the market, unlike in case of corporate bonds, and so the obtained results could be used directly to analyse market index spreads.

The rest of the paper is organized as follows: Section 1 deals with the relationship between macroeconomic dynamics and default intensities. Section 2 introduces the estimation procedure and specifies the data used in the estimation. Finally, Section 3 summarizes and provides an outlook for further research.

\section{MODEL SETUP AND PRICING}

In this section we present our approach how to model the interaction between macroeconomic and default intensity dynamics. The default intensity dynamics is modelled using the class of so called basic affine jump-diffusion processes. It is assumed that the default intensity is driven by two components: idiosyncratic (or firm specific) and systematic (or market wide). After specifying the multivariate default dynamics, we turn to the pricing of specific type of credit derivatives, so called CDS.

CDS is a swap designed to transfer the credit exposure of fixed-income products between parties. The buyer of a credit default swap receives credit protection, whereas the seller of the swap guarantees the creditworthiness of the product. By 
doing this, the risk of default is transferred from holder of the fixed-income security to the seller of the swap.

The pricing of CDS in this framework is by now standard and it requires setting the market value of the payment made by the buyer equal to the market value of the payment made by the seller. The important and in this context the key feature is that the standard approach to pricing CDS allows expressing the prices (i.e. CDS premium) as a function of recovery rates, default intensity parameters and prices of riskless zero-coupon bonds.

The above relationship, however, has one shortcoming. It does not investigate the connection between corporate default intensity and macroeconomic dynamics. In order to redress this shortcoming the authors employ a dynamic term structure model entirely based on macroeconomic factors. Bond prices are exponential-affine in the state-variables of a forwardlooking macromodel and are derived assuming absence of arbitrage. The dynamics of bond prices and entire term structure are interpreted in terms of macroeconomic fundamentals, i.e. inflation, output gap and short-term policy interest rate. This allows extending the above empirical framework in a way so that the dynamics of the default intensity is explained in terms of macroeconomic variables, CDS premium and recovery rates.

\section{A. GeneralMacroeconomic Setup}

We rely on structural macroeconomic model of the following form

$$
\begin{aligned}
& \pi_{t}=\frac{\mu_{\pi}}{12} \sum_{i=1}^{12} \mathrm{E}_{t}\left[\pi_{t+i}\right]+\left(1-\mu_{\pi}\right) \sum_{i=1}^{3} \delta_{\pi i} \pi_{t-i}+\delta_{x} x_{t}+\varepsilon_{t}^{\pi} \\
& x_{t}=\frac{\mu_{\pi}}{12} \sum_{i=1}^{12} \mathrm{E}_{t}\left[x_{t+i}\right]+\left(1-\mu_{x}\right) \sum_{i=1}^{3} \zeta_{x i} x_{t-i}-\zeta_{r}\left(r_{t}-\mathrm{E}_{t}\left[\pi_{t+1}\right]+\varepsilon_{t}^{x}\right.
\end{aligned}
$$

where $\pi_{t}$ - the inflation,

$x_{t}$ - output gap,

$r_{t}$ - interest rate.

All variables are expressed at the monthly frequency. Inflation is defined as $\pi_{t} \equiv \ln P_{t}-\ln P_{t-12}$, where $P_{t}$ is the price level at $t$.

Both equations can be derived from the first principles and they have been employed by several authors including $\mathrm{Wu}$ [16], Rudebusch and $\mathrm{Wu}$ [13] and in the literature on term structure modelling by Bekaert et al. and Hoerdahl et al. (for more details, see [2], [10]).

The first equation shows that the prices will be set as a mark-up on marginal cost (output gap term in the equation) and there are price stickiness (the expected inflation term) and inflation inertia (the lag terms) in the economy. On the other hand, output gap equation is explained by the short term real interest rate and the intertemporal smoothing motive (the forward looking term), which is the main component of aggregate demand.
The rational expectations equilibrium is solved by specifying the monetary policy rule implemented by the central bank. The authors rely on the "simple rule" that is consistent with the formulation in Clarida-Gali-Gertler rule that is consistent with the formulation in Hoerdahl et al. [10]:

$$
r_{t}=(1-\rho)\left(\beta\left(\mathrm{E}_{t}\left[\pi_{t+11}\right]-\pi_{t}^{*}\right)+\rho r_{t-1}+\eta_{t}\right.
$$

where $\pi_{t}^{*}$ is the perceived inflation target, which follows autoregression process, i.e.

$$
\pi_{t}^{*}=\phi_{\pi} \pi_{t-1}^{*}+u_{\pi^{*}, t}
$$

and $\eta_{t}$ is a "monetary policy shock". The above equation shows that the central bank responds to the deviations of expected inflation from the inflation target (first part) and is also motivated by interest rate smoothing concerns (the second part). All the three structural macroeconomic shocks and $u_{\pi^{*}, t}$ are uncorrelated and normally distributed with constant variance. The solution of above system is based on the approaches developed by Soederlind and Hoerdahl et al (for more details, please, see [10], 15]).

\section{B. Pricing of Bonds}

For the pricing of bonds, let $Z_{t}$ be the transformed vector that, among other things, includes levels of inflation, the output gap, and the short rate. The new vector is defined as

$$
Z_{t}=D X_{t}
$$

for some selection matrix $D$. Note that because of $\mathrm{X}_{2, t+1}=C \mathrm{X}_{1, t}$ the state vector $\mathrm{Z}_{t}$ can also be expressed as $Z_{t}=\hat{D} X_{1, t}$. In empirical applications $\hat{D}$ is chosen such that bond prices are expressed as functions of the levels of macrovariables, rather than of their shocks.

Next assuming the standard dynamic arbitrage-free term structure literature one can define nominal pricing kernel $m_{t+1}$, which prices all nominal bonds in the economy, such as $m_{t+1}=\exp \left(-r_{t}\right) \frac{\phi_{t+1}}{\phi_{t}}$ where the market price of risk $\lambda_{t}, \phi_{t+1}$ is conditionally log-normal process $\phi_{t+1}=\phi_{t} \exp \left(-\frac{1}{2} \lambda_{t}^{\prime} \lambda_{t}-\lambda_{t}^{\prime} \varepsilon_{t+1}\right)$, where $\varepsilon_{t+1}$ is a vector of standard normal shocks such that $\zeta_{1, t+1}=\sum \zeta_{t+1}$.

Asuming that the market prices of risk associated with the uncertainty stemming from the structural shocks are affine in the state vector $Z_{t}$ :

$$
\lambda_{t}=\lambda_{0+} \lambda_{1} Z_{t}
$$


Thus the price of n-period nominal bond is an exponentialaffine function of the state variables, i.e.

$$
p_{t}^{n}=\exp \left(\overline{\mathrm{A}}_{n}+\overline{\mathrm{B}}_{n}^{\prime} \mathrm{Z}_{t}\right)
$$

where $\overline{\mathrm{A}}_{n}$ and $\overline{\mathrm{B}}_{n}^{\prime}$ are recursively defined parameters that depend on the maturity $n$.

\section{Pricing of Credit Default Swaps}

For pricing CDS we rely on studies made by Duffie, Garleanu, and Longstaff et al. (for more details, see [6], [11], [14]). The subsection starts from a continuous time multivariate intensity-based model to price CDS. Then, the pricing formula with a natural discretization is derived. The combined formula provides a unified empirical framework for dynamics of default intensities and macroeconomic dynamics.

Considering an underlying pool of $\mathrm{N}$ entities over time horizon $\mathrm{T}$, for each entity $\mathrm{i}=1, \ldots, \mathrm{N}, \tau_{i}$ denotes the time of default. A constant homogeneous recovery rate, $\delta \in[0,1)$ is assumed throughout the text. In addition, the authors of the paper fix a filtered probability space $\left\{\Omega, F,\left(F_{t}\right)_{t \in[0, T]}, \mathrm{P}\right\}$ satisfying the usual conditions. Up to technical conditions, the absence of arbitrage implies the existence of equivalent martingale measure $Q$ such that the price at time $t$ of a security paying an amount $\mathbf{Z}$ at a stopping time $\tau>t$ is given by

$$
V_{t}=\mathrm{E}_{t}^{Q}\left(e^{-\int_{t}^{\tau} r_{s} d s} \mathrm{Z}\right),
$$

where $\mathrm{E}_{t}^{Q}$ denotes expectation under $\mathrm{Q}$ conditional on all available information up to time $t$.

Under the equivalent martingale measure $Q$, for each individual firm $i$, a default time $\tau_{i}$ is modelled as the first jump of a Cox process, also known as doubly stochastic Poisson process. Specifically, the default intensity of obligor $i$ is a non-negative real-valued progressively measurable stochastic process composed of a common and an idiosyncratic component in the following way

$$
\Lambda_{i, t}=a_{i} \mathrm{Y}_{t}+V_{i, t}
$$

where $a_{i}>0$ is a constant and $\mathrm{Y}$ and $V_{i}$ are independent affine processes. Suppose the common component follows

$$
d \mathrm{Y}_{t}=\kappa_{\mathrm{Y}}\left[\theta_{\mathrm{Y}}-\mathrm{Y}_{t}\right] d t+\sigma_{\mathrm{Y}} \sqrt{\mathrm{Y}_{t}} d W_{\mathrm{Y}, t}+d J_{\mathrm{Y}, t}
$$

and the idiosyncratic components follow

$$
d V_{i, t}=\kappa_{i}\left[\theta_{i}-V_{i, t}\right] d t+\sigma_{i} \sqrt{V_{i, t}} d W_{i, t}+d J_{i, t}
$$

for $\mathrm{i}=1 \ldots \mathrm{N}$, where

- $W_{\mathrm{Y}}, W_{1}, \ldots, W_{N}$ are independent Wiener processes
- $J_{\mathrm{Y}}, J_{1}, \ldots, J_{N}$ are independent pure jump processes, independent of the Wiener processes

- the jump times of $J_{\mathrm{Y}}, J_{1}, \ldots, J_{N}$ are those of a series of Poisson process with intensities $l_{\mathrm{Y}}, l_{1}, \ldots, l_{N}$

- the jump sizes $J_{\mathrm{Y}}, J_{1}, \ldots, J_{N}$ are independent of the jump times and follow exponential distributions with means $\mu_{\mathrm{Y}}, \mu_{1}, \ldots, \mu_{N}$.

For pricing CDS we calculate risk-neutral survival probabilities. The above mentioned class of affine processes allows one to define the survival probabilities explicitly, as follows

$$
\begin{aligned}
& \left.\left.\operatorname{Pr}\left(\tau_{i} \leq t\right)=1-\mathrm{E} e^{-\int_{0}^{\int} \Lambda_{i, s} d s}\right\rfloor=1-\mathrm{E} e^{-a_{i} \int_{0}^{1} \mathrm{Y}_{s} d s}\right\rfloor \times\left\lfloor e^{-\int_{0} V_{i, s} d s}\right\rfloor \\
& =1-e^{C\left(t ; \kappa_{\mathrm{Y}}, a_{i} \theta \mathrm{Y}, \sqrt{a_{i}} \sigma_{\mathrm{Y}}, l_{\mathrm{Y}}, a_{i} \mu_{\mathrm{Y}}\right) a_{i} \mathrm{Y}_{0}} \times \\
& \times e^{C\left(t ; \kappa_{i}, \theta_{i}, \sigma_{i}, l_{i}, \mu_{i}\right)+D\left(t ; \kappa_{i}, \sigma_{i}\right) V_{i, 0}}
\end{aligned}
$$

The general procedure for pricing credit derivatives is setting the values of the premium leg Prem (the market value of the payments made by the buyer of protection) equal to the value of the protection leg Prot (the market value of the payment made by the seller of protection) and solve for the fair credit spread. Formally, the value of the protection leg in a $\mathrm{T}$ year CDS is

$$
\operatorname{Pr} o t(0, T)=\mathrm{E}\left[e^{-\int_{0} r_{s} d s} 1_{\{\tau \leq T\}}(1-\delta)\right\rfloor
$$

Suppose the CDS contract specifies that the annual premium, $\mathrm{S}$ is paid in arrears at $t_{1}, t_{2} \ldots, t_{M}=T$. Premium payments are made conditional on survival of the reference entity, and in the event of default, an accrual premium payment is made for the period since the previous payment date. Hence, the value of the payment leg is

$$
\begin{gathered}
\operatorname{Pr} e m(0, T ; S)=E\left[\sum_{j=1}^{M} e^{-\int_{0}^{t_{j}} r_{s} d s} 1_{\left\{\tau>t_{j}\right\}} S\left(t_{j}-t_{j-1}\right)+\right. \\
\left.+e^{-\int_{0}^{\tau} r_{s} d s} 1_{\left\{t_{j-1}<\tau \leq t_{j}\right\}} S\left(\tau-t_{j-1}\right)\right]
\end{gathered}
$$

Note that $1_{\{\tau \leq T\}}, 1_{\left\{\tau>t_{j}\right\}}, 1_{\left\{t_{j-1}<\tau \leq t_{j}\right\}}$ are Heaviside step functions.

With discretization and independence assumptions between recovery rates, interest rates, and default events the value of the protection leg is 


$$
\begin{gathered}
\operatorname{Pr} o t(0, T)=(1-\delta) \sum_{j=1}^{M} \rho_{0}^{\frac{t_{j}+t_{j-1}}{2}}\left[\operatorname{Pr}\left(\tau \leq t_{j}\right)-\right. \\
\left.-\operatorname{Pr}\left(\tau \leq t_{j-1}\right)\right]
\end{gathered}
$$

Similarly, the value of the premium leg is

$$
\begin{gathered}
\operatorname{Pr} \operatorname{em}(0, T ; S)=S \sum_{j=1}^{M}\left(t_{j}-t_{j-1}\right) \rho_{0}^{t_{j}} \operatorname{Pr}\left(\tau>t_{j}\right)+ \\
+\frac{t_{j}-t_{j-1}}{2} \rho_{0} \frac{t_{j}+t_{j-1}}{2}\left[\operatorname{Pr}\left(\tau \leq t_{j}\right)-\operatorname{Pr}\left(\tau \leq t_{j-1}\right)\right]
\end{gathered}
$$

The fair CDS premium, is then given as the solution to $\operatorname{Prem}(0, \mathrm{~T} ; \mathrm{S})=\operatorname{Prot}(0, \mathrm{~T})$. In turn, given a CDS premium and a recovery rate implied default intensity parameters can be found as the solution to the same equation.

\section{MODEL VALIDATION}

The starting point of the model validation is data collection, realised in Working Project 1 "Data Collection and Database Consolidation" together with the collection of any other extra information that could allow to draw geographical maps of the economic situations of individual states. The authors collect macroeconomic and financial predictor variables of financial markets: (1) macroeconomic data (e.g. interest rates, inflation rates, Real GDP), (2) CDS market indicators data.

The second point is the development of scientific and technological support in order to visualize the model and elaborate collected information. This research is in line with similar projects that are presently starting in the world. In particular, the authors are in contact with:

(i) the Principal Economists and Experts from the European Central Bank (particularly the European Systemic Risk Board), Bundesbank (Germany), and the Central Bank of Italy,

(ii) scientists and young researchers from the Swiss National Centre of Competence in Research FINRISK, ETH Swiss Federal Institute of Technology in Zurich,

(iii) such well-known Professors as Duffie Darrell, Paul Embrechts and Jerome Detemple,

in order to ensure compatibility between the research and model developed and described in the paper and similar stateof-the-art activities. This activity constitutes the core of default intensities visualization and macroeconomic analysis by means of the forecast of the financial crisis. This activity constitutes the core of Working Project 2"Joint Model of Corporate Default Intensities and Macroeconomic Dynamics Visualization and Validation".

Working Project 3 carries out "Estimation Procedure". Estimation procedure is described and empirical model is defined in order to test the unified framework. Data analysis is incorporated in estimation.

\section{A. Data Collection and Database Consolidation}

Various sources are used for collecting the data: International Swaps and Derivatives Association (ISDA) Surveys and Market Statistics, the Bank for International Settlements (BIS) Surveys and Market Statistics, the FED and the European Central Bank Surveys. For collecting CDS market data such market data providers as Markit, Bloomberg, Barclays Capital and Morgan Sttanley are used.

\section{Credit Derivatives Data Source}

We construct a historical synthetic time series of spreads for fixed set of companies mainly using data from Markit. Markit data allows to focus on a fixed group of firms, thus to achieve consistency in the series across time as well as analyse data over the longest period possible.

Markit provided 5, 7, and 10 years iTraxx Europe index and tranche bid- and ask-spreads for the period September 2004 to April 2010. Markit provided 5, 7, and 10 year iTraxx Europe tranche mid-market spreads for the period August 2004 to April 2010. Morgan Stanley provided 5,7, and 10-years iTraxx Europe index and tranche bid- and ask-spreads for the period March 2004 to April 2010.

Markit provided 1, 5, 7, and 10 year CDS mid-market spreads for the iTraxx Europe members for the period August 2004 to April 2010.

The group of companies considered are the members of iTraxx Europe index. Most ofcompanies have an external credit rating in the range of $\mathrm{A}+/ \mathrm{A} 1$ to $\mathrm{BBB}-/ \mathrm{Baa} 3$. Five sectors are considered and analysed: consumer, energy, financial, industrial, and technology, media and telecommunications. Synthetic series of index and sector spreads are constructed as equal-weighted averages of spreads on single-name contracts.

\section{Data design}

The source of the data used for model approbation is monthly CDS spreads. In estimation, maturities of 12, 60, 84 and 120 months are used. This is done for two reasons. First, term structure of spreads is upward sloping at lower spread levels, in particular, there have been large differences over the past couple of years between one-year and five year CDS rates. Second, second spreads are highly persistent and much of their variation occurs over lower frequencies, such as one month or more.

\section{Interest Rate Data}

3-months, 6-months, 1-year, 3-year, 5 year and 10-year Euro LIBOR swap rates are used to estimate the riskless discount function $\mathrm{Bt}(\mathrm{T})$ at each point in time t. Specifically, for these standard maturities the authors use swap rates from the Bloomberg system. Swap rates are widely regarded as more reliable than Treasury yields as a source for riskless interest rates. Treasury securities often contain a convenience yield, because they can be posted as collateral and may allow borrowing at special repo rates.

As a benchmark for the money and capital markets Euro Over Night Index Average (Eonia) reference rates are used which are calculated by the European Central Bank and published by Thomson Reuters. 


\section{Inflation Rate and GDP}

A panel of macroeconomic time series is constructed from the Federal Reserve Economic Database (FRED).

The year-on-year inflation rate series are constructed using the Consumer Price Indexes (CPI).

For the output gap is applied the log of total industrial production using quadratic trend. Each datapoint is obtained by fitting a quadratic trend to the original series up to that point. The approach helps to ensure that forecast at time t does not rely on information unavailable at that point in time.

\section{B. Joint Model of Corporate Default Intensities and \\ Macroeconomic Dynamics Visualization and Validation}

While the theoretical framework and empirical analysis is the final deliverable of the research, it is crucial to test a model already during the early stage of the development. This means that all these activities are processed through a continuous feedback from data and theoretical framework analysis to model, validation and visualization and back to data analysis. The management and dissemination of this workflow is ensured by the discussions during the conferences, seminars, workshops, meeting and discussion with experts and principal economists from central banks of Europe.

Particularly, the model was successfully presented and discussed during NCCR FINRISK and the European Central Bank workshops, meetings with several central banks' experts, as well as by correspondence with Principal Economists and Statisticians from the Central Bank of Italy, RTU and ETH Zurich scientific conferences. As a Phd intern at the Directorate of Financial Stability and Supervision of the European Central Bank, TatjanaŽidul̦ina participated in the project devoted to financial stability issues including CDS market liquidity indicators. The project allowed validating the model.

European central bank experts used the following criteria for the model validation: scientific novelty of theoretical framework approach, structure of macro and empirical models, moddeling of defaultable claims. Summarising the comments and remarks of the model made by central bank experts the following conclusions are drawn:

- Scientific novelty: experts were inspired by a variety of macro literature use by the authors. They proved that authors provide a comprehensive theoretical framework for modelling defautable bonds taking into account various macroeconomic factors. Developed macromodel covers nonlinear effects.

- Comments on macromodel: First, interest rate used in the model is exogenously set by central bank, therefore, there is no clear understanding if firms and investors have access to the short rate. Second, the model implies only positive interest rate, but it can also suggest negative rate.

- Recommendation on empirical model: to use Kalman filter that suggests the connection of errors to initial model.

Based on the comments and remarks the model was modified and improved.

\section{Estimation Procedure}

The following subsection describes the detailed computational estimation procedure for the fair CDS premium, S.

Solving the equation $\operatorname{Prot}(0, \mathrm{~T})=\operatorname{Prem}(0, \mathrm{~T}, \mathrm{~S})$ for $\mathrm{S}$ and using formulas 7 and 12 the authors can express $S=\frac{\Gamma}{K}$, where

$$
\begin{array}{r}
\Gamma=(1-\delta) \sum_{j=1}^{\mathrm{M}} e^{\frac{\overline{\mathrm{A}}_{t_{j}+t_{j-1}}}{2}+\overline{\mathrm{B}}^{\prime} \frac{t_{j}+t_{j-1}}{2} \mathrm{Z}_{0}} \times \\
\times\left[e^{C\left(t_{j-1}\right)+D\left(t_{j-1}\right) a_{i} \mathrm{Y}_{0}} e^{C^{\prime}\left(t_{j}-1\right)+D^{\prime}\left(t_{j-1}\right) V_{i, 0}}-\right. \\
\left.-e^{C\left(t_{j}\right)+D\left(t_{j}\right) a_{i} \mathrm{Y}_{o}} e^{C^{\prime}\left(t_{j}-1\right)+D^{\prime}\left(t_{j-1}\right) V_{i, 0}}\right] \\
\mathrm{K}=\sum_{j=1}^{\mathrm{M}}\left[\left(t_{j}-t_{j-1}\right) P_{j}+\frac{t_{j}-t_{j-1}}{2} R_{j}\right]
\end{array}
$$

with

$$
\begin{array}{r}
P_{j}=e^{\overline{\mathrm{A}}_{t_{j}}+\overline{\mathrm{B}}_{t_{j}}^{\prime} \mathrm{Z}_{0}} e^{C\left(t_{j}\right)+D\left(t_{j}\right) a_{i} \mathrm{Y}_{o}} e^{C^{\prime}\left(t_{j}-1\right)+D^{\prime}\left(t_{j-1}\right) V_{i, 0}}, \\
R j=e^{\frac{\overline{\mathrm{A}}_{t_{j}+t_{j-1}}}{2}+\overline{\mathrm{B}}^{\prime} \frac{t_{j}+t_{j-1}}{2} \mathrm{Z}_{0}} \times \\
\times\left[e^{C\left(t_{j-1}\right)+D\left(t_{j-1}\right) a_{i} \mathrm{Y}_{0}} e^{C^{\prime}\left(t_{j}-1\right)+D^{\prime}\left(t_{j-1}\right) V_{i, 0}}\right. \\
\left.-e^{C\left(t_{j}\right)+D\left(t_{j}\right) a_{i} \mathrm{Y}_{o}} e^{C^{\prime}\left(t_{j}-1\right)+D^{\prime}\left(t_{j-1}\right) V_{i, 0}}\right] .
\end{array}
$$

In order to estimate the whole set of parameters the author of the paper implement a two-step estimation procedure:

First, from equation (7)and $Z_{t}=\hat{D} X_{1, t}$, we are getting:

$$
y_{t}^{n}=\mathrm{A}_{n}+\mathrm{B}_{n}^{\prime} \mathrm{X}_{1, t} \text {, }
$$

where $\mathrm{A}_{n} \equiv-\frac{\overline{\mathrm{A}}_{n}}{n}$ and $\mathrm{B}_{n}^{\prime} \equiv \frac{-\hat{B}_{n}^{\prime}}{n}$.

Second, assuming orthogonality of measurement shocks to the unobservable states we use maximum likelihood within Kalman filter framework to estimate term structure model

$$
\begin{gathered}
y_{t}^{n}=\mathrm{A}_{n}+\mathrm{B}_{n, 0}^{\prime} \mathrm{X}_{1, t}^{0}+\mathrm{B}_{n, u}^{\prime} \mathrm{X}_{1, t}^{u}+\omega_{t}, \\
\mathrm{X}_{1, t+1}^{u}=\mathrm{M}^{u} \mathrm{X}_{1, t}^{u}+v_{t+1},
\end{gathered}
$$

where $\omega_{t} \sim \mathrm{N}(0, R)$, and $v_{t} \sim \mathrm{N}(0, Q)$ and $\mathrm{X}_{1, t}^{u}$ are the unobservable variables included in the $\mathrm{X}_{1, t}$ vector. 
Finally, we estimate the remaining set of parameters $\Theta$ that are related to the dynamics of default intensities and also include the recovery rates:

$$
S=\frac{\Gamma\left(\hat{P}_{0} \frac{t_{j}+t_{j-1}}{2} ; \Theta\right)}{K\left(\hat{P}_{0}^{t}{ }_{j}, \hat{P}_{0} \frac{t_{j}+t_{j-1}}{2} ; \Theta\right)},
$$

where $\hat{P}$ are fitted values (prices) from the first step. Since it is non-linear equation the authors again rely on maximum likelihood estimation.

\section{CONCLUSION}

This paper presents the model of CDS pricing taking into account various macroeconomic factors. The authors develop intensity based theoretical framework where structural model combined with affine intensity specification.

The empirical implication of the pricing relationship is that the authors, first, employ a dynamic term structure model based on macroeconomic factors, second, define prices for zero-coupon bonds, find the implied default intensity parameters and their dynamics, finally, observe CDS premium and recovery rates.

The joint model of corporate default intensities and macroeconomic dynamics was validated by the European central bank experts as well as during seminars, workshops and conferences. European central bank experts used the following criteria for the model validation: scientific novelty of theoretical framework approach, structure of macro and empirical models, moddeling of defaultable claims. The authors received positive feedback on their theoretical framework and some recommendations. Based on the comments and remarks the empirical model was modified by using Kalman filter.

Modelling and estimating the multivariate dynamics of default intensities using the macroeconomic data on interest rates, inflation rate and output gap allows us to better pin down the corporate default intensity dynamics and get precise parameters.

The developed CDS pricing model has a practical implementation. It may be used in pricing CDS by market agents, as a benchmark indicator by central banks, and as an indicator in default events analysis and financial stability assessment and prediction of a single company or industry sectors.

There are several main avenues to explore in the future research. First, it would be desirable to incorporate countercyclical recovery rates, which are potentially quite important for pricing CDS that are heavily exposed to tail. Second,the model may suggest such macroeconomic variable as negative rates. Third, analysis may include estimatimation of such financial predictor variable as equity indexes which are available for investors in financial markets.

\section{REFERENCES}

[1] Amato, J.D. "Risk Aversion and Risk Premia in the CDS market". BIS Quarterly Review, December 2005. [Online]. Available: http://www.bis.org/publ/qtrpdf/r_qt0512e.pdf [Accessed: August 2009]
[2] Bekaert, G., Cho, S., Moreno, A., "New Keynesian Macroeconomics and the Term Structure". Journal of Money, Credit and Banking, Blackwell Publishing, vol. 42(1), 2010, pp 33-62.

[3] Berndt, A., Douglas, R., Duffie, D., Ferguson, M., Schranz, D., "Measuring Default Risk Premia from Default Swap Rates and EDFs", BIS Working Papers, No. 173, 2005. [Online]. Available:

[4] http://www.bis.org/publ/work173.pdf [Accessed: August 2009]

[5] Duffie, D., Saita, L., Wang, K., "Multi-Period Corporate Default Prediction with Stochastic Covariates". Journal of Economics 83, (8), 2007, pp. 635-665

[6] Duffie D., Eckner,A.,Horel,G.,Saita,L. "Frailty Correlated Default". Stanford University Working Paper, 2006. [Online]. Available:

[7] http://papers.ssrn.com/sol3/papers.cfm?abstract_id=1314771 [Accessed: August 2009]

[8] Duffie, D., Garleanu, N., "Risk and Valuation of Collateralized Debt Obligations". Financial Analysts Journal 57, 2001, pp. 41-59.

[9] Eckner A., "Computational Techniques for basic Affine Models of Portfolio Credit Risk". Stanford University Working Paper, 2007. [Online]. Available: http://www.eckner.com/papers/bAJD_comp.pdf [Accessed: July 2008]

[10] Eckner A., "Risk Premia in Structured Credit Derivatives". Stanford University Working Paper, 2008. [Online]. Available:

[11] http://www.eckner.com/papers/rpscd.pdf [Accessed: June 2008]

[12] Giesecke, K., Goldberg, L.R., "A top down Approach to Multi-Name Credit”. Working paper, 2005. [Online]. Available:

[13] http://papers.ssrn.com/sol3/papers.cfm?abstract id=1142152 [Accessed: July 2010]

[14] Hoerdahl, P., Tristani, O., Vestin, D., "A joint econometric model of macroeconomic and term-structure dynamics". Journal of Econometrics No. 131 2006, pp. 405-444.

[15] Longstaff, F. A., Rajan, A., "An Empirical Analysis of the Pricing of Collateralized Debt Obligations”. Journal of Finance, 63, (2), 2008, pp. 529-563.

[16] Mortensen A., 2006. Semi-Analytical Valuation of Basket Credit Derivatives in Intensity-Based Models. Working Paper, 2006, pp. 08-26.

[17] Rudebusch, G., Wu, T., "A macro-finance model of the term structure, monetary policy, and the economy". Federal Reserve Bank of San Francisco: Working Paper No. 2003-17.

[18] Saita, L., The Puzzling Price of Corporate Default Risk. Stanford University Working Paper, 2006. [Abstract] Available: online

[19] http://www2.1se.ac.uk/fmg/documents/events/.../513 LeandroSaita Job Market.pd [Accessed June 2008]

[20] Soederlind P., "Solution and estimation of RE macromodels with optimal policy”. European Economic Review Vol. 43, 1999, pp.813823.

[21] Wu, T., "Macro factors and the affine term structure of interest rates. Federal Reserve Bank of San Francisco" Working paper 2002, pp. 0206. [Online] Available:

[22] http://papers.ssrn.com/sol3/papers.cfm?abstract id=712241 [Accessed: April 2008]

TatjanaZidulinais a candidate for $\mathrm{PhD}$ degree in Economics, holds a Master's in Economics in 2003, Bachelor's in Management in 2001 from Riga Technical University, advanced diploma from Copenhagen Business School in 2004 and various certificates from the ETH Zurich and Swiss Banking Institute all achieved with honours in 2008. The author focuses on modelling financial risks and financial instabilities in banking and financial markets.TatjanaZidulinaworks as a Risk Officer at the Private Banking in Zurich, Switzerland. The author has a strong academic background in Risk Management. As a research analyst Tatjana gained experience at the Directorate of Financial Stability and Supervision of the European Central Bank during 2008-2009 and as risk analyst at Risk Management Department of the SEB bank during 2005-2007. In the 2008 year she worked as a researcher on financial risks at the Swiss Banking Institute, particularly examining the impact of economic and political forces on financial markets. The ultimate goal of her research was to provide quantitative assessment of default risk components. Current research interests are modelling default event risk premium, defining stability measures with respect to liquidity risk, investigating dynamics of systemic risk in financial market and financial networks.TatjanaZidulinawas awarded with the following grand: Swiss Federal scholarship ESKAS from Bern, Switzerland in July 2007, GEBERT RÜF STIFTUNG Foundation grand from Basel, Switzerland in January 2007, award of the Society of Economics for her thesis "Banking Risk Management Problems" from Science Council Riga, Latvia in 2001.

Contacts: e-mail: Tatajan.Zidulina@rtu.lv 
A graduate of Latvian University, Faculty of Physics and Mathematics, Maris Buikis received his $\mathrm{PhD}$ in 1965, became an associate Professor in Riga Technical University in 1996 and full professor in 2005. Given biennially by the Latvian Actuaries Association to the mathematicians he has made the most significant contribution to field of statistic probability and insurance premium modelling.

MarisBuikis is Doctor of Mathematics, Professor of the International Business and Customs Institute, Head of the Department of Probability Theory and Mathematical Statistics at Riga Technical University. During 45 years he has taught at Latvian University, Riga Technical University and Riga International School of Economics and Business Administration, Latvia.
His previous research was devoted to solving stochastic differential equations. His current professional research interests include dynamical systems with random perturbation: mathematics of finance and security portfolio.

$\mathrm{He}$ has promoted $2 \mathrm{PhD}$ theses and author about 20 scientific publications, 6 study books and numerous journal and conference papers. In addition Prof. Buikis is a Editorial Board member of the Scientific Journal of Riga Technical University, section „Information Technology and Management Science” and member of the scientific committee of the RTU International Scientific Conference since 2010.

\section{Māris Buiķis, Tatjana Židuḷina. Korporatīvas saistību nepild̄̄šanas intensitātes modelis un makroekonomikas dinamika}

Rakstā tiek piedāvāts integrēts modelis, kurā vienkāršs strukturāls makroekonomikas modelis ir apvienots ar kombinēto modeli, kas raksturo korporatīvo saistību nepildīšanas intensitāti. Galvenā rakstā risinātā problēma ir vienota empīriska modeḷa izstrāde. Izstrādes procesā raksta autori (i) izmanto strukturālu makroekonomikas modeli, nevis ierobežotas formas modeli un (ii) apvieno strukturālu makroekonomikas modeli ar korporatīvosaistību nepildīšanas intensitātes modeli. Integrēta modela pielietojums lauj iegūt precīzākus korporatīvo saistību nepildīšanas intensitātes parametrus un parādu atgūšanas līmeni, ko varētu izmantot, lai precīzāk veiktu kredītsaistību nepild̄̄̌sanas mijmaiņas darījumu (CDS) cenu aprēķinu. Svarīga raksta iezīme ir tas, ka analīzē tiek izmantoti makroekonomiskie dati: procentu likmes, inflācijas rādītāji un nacionālā kopprodukta dati. Viena emitenta strukturētie kredīta instrumenti sniedz milz̄̄gu informācijas daudzumu par investoru attieksmi pret risku kredītu tirgos. Tādējādi, izmantojot makroekonomiskus datus, ir iespējams precīzāk novērtēt riska neitrālas korporatīvo saistību nepildī̌sanas iemeslus un tās intensitātes dinamiku.

Modeli ir pozit̄ivi novērtējuši Eiropas Centrāāās bankas eksperti un speciālisti. Eiropas Centrālās bankas eksperti novērtēja modeli, izmantojot sekojošus kritērijus: zinātniskā novitāte, makroekonomikas un empīriskā modę̣a struktūra, korporatīvo saistību nepildī̌šanas modelēšana. Viṇu atsauksmes un komentāri palīdzēja uzlabot raksta teorētisko dạu un gala modeli. Pēc ekspertu ieteikuma modelis tika papildināts ar Kalmana filtru, kas palīdz noteikt saikni starp modelēšanas kḷūdām un sākotnējo modeli un precīzāk aprēḳināt parādu atgūšanas likmes.

CDS cenu veidošanas modelim ir praktisks pielietojums. To var izmantot finanšu tirgus dalībnieki, aprēkininot CDS prēmiju, centrālās bankas kā kontroles rādītāju un korporatīvo saistību nepildīšanas rādītāju, kā arī vērtējot un prognozējot vienas kompānijas vai industrijas finanšu stabilitāti.

Turpmākie pētījumu virzieni ir saistīi ar korelētu parādu atgūšanas likmju iekḷaušanu modelī, kuriem ir liela nozīme CDS cenu noteikšanā, jo tās ir ḷoti atkarīgas no mazas varbūtības riska faktoriem. Tiek izskatīta iespēja papildināt modeli arī ar papildus makroekonomiskajiem rādītāiem, piemēram, ar negatīvām procentu likmēm. Būtu interesanti novērtēt korporatīvo saistību nepild̄̄̌nanas dinamiku, lietojot tādu finanšu rādītāju, kā kapitāla indeksus, kurus pielieto investori starptautiskajos finanšu tirgos.

\section{Марис Буйкис, Татьяна Жидулина. Модель интенсивности корпоративных дефолтов и макроэкономическая динамика}

В данной статье представлена объединенная модель, в которой структурная макроэкономическая модель сочетается с моделью интенсивности корпоративного невыполнения обязательств, т.е. дефолтов. Основная задача авторов представить эмпирическую модель. Для этого авторы статьи используют (i) структурную макроэкономическую модель, вместо обычной модели приведенной формы и (ii) сочетают в структурной модели макроэкономики мультивариативную динамику корпоративных дефолтов. Объединенная модель позволяет получить более точные параметры по данным корпоративного невыполнения обязательств и использовать полученные результаты для более точного расчета премии своп. Важной особенностью статьи является использование данных по процентным ставкам, инфляции, валового продукта. Одноименные структурные кредитные продукты содержат огромное количество информации о кредитных рынках и предпочтениях инвесторов по отношению к рискам. Таким образом, моделирование и оценка динамики корпоративных дефолтов с использованием макроэкономических данных позволяет нам лучше изучить причины корпоративных дефолтов.

Модель была протестирована и одобрена экспертами и ведущими специалистами Европейского Центрального банка. Эксперты Европейского Центрального банка оценили модель по следующим критериям: научное новизна, структура макро и эконометрической моделей, способ моделирования дефолтов. Полученные отзывы и комментарии, включая критику со стороны экспертов и ученых, были приняты во внимание и позволили улучшить теоретическую основу и видоизменить модель. В частности, использование фильтра Калмана позволяет выявить ошибки первоначальной модели и вычислить уровень возврата.

Модель ценообразования CDS имеет практическое применение. Она может быть использована центральными банками как контрольный показатель и как показатель возможного дефолта, представителями финансового рынка при расчете премии CDS, а также при оценке и прогнозировании финансовой стабильности отдельной компании или отрасли промышленности.

Научное исследование можно продолжить, изучая причины корпоративных дефолтов (в том числе цикличность уровня возврата), которые подвержены риску и очень важны для ценообразования CDS. Модель можно дополнить такими макроэкономическими переменными как негативные процентные ставки. Было бы интересно проследить динамику изменения дефолтов, включив такой финансовый показатель как индексы рынков капитала, к которым имеют доступ инвесторы на финансовых рынках. 